\title{
高分子希薄溶液の粘弾性 $(\mathrm{I})$
}

最近の数年間飞高分子希薄溶液の粘弹性の研究に多くの重要な発展がみられ た。線状コイル分子については，バネ鎖模型による分子論が湮注確立した。 Rouse-Sittel によって良溶媒中で検証をされた Rouse の素抜り理論に，流体 力学的相互作用を考虑した Zimm-Tschoegl 理論や，さらに排除体積効果を 入れたTschoeg1 理論などが適当な条件の下で線状コイル分子の剛性率の分散 をよく説明することが，Ferry，Lamb，著者らの各グループによって独立に見 出された。これらの研究からさらに多くの新しい問題が提起された。立た棒状 高分子についての Kirkwood-Auer や Cerf-Scheraga 理論の正当性について は，Ferry らがタンパク質を用いて，著者らはポリアミノ酸を試料として，定 性的に確かめた。

これらの問題について，主要な測定装置を含めて解説する。

\section{田中秀次郎* . 坂 西 明 郎**}

\section{1.は し がき}

高分子希薄溶液の物性の研究の主な目的は弧立した 1 個の分子の性質を分子論的に理解することである。一方 粘弾性の研究とは物質の機械的性質を調べることであ り，固体の場合には実用上材料としての性質を知ること が重要な問題になる。しかし希薄溶液の場合には,やは り分子レベルでの応力と变形の関係を知ることが興味の 中心になる。この場合, セグメントのミクロブラウン運 動によって，加えた外力にエネルギーの散逸を伴う。し たがって粘弾性を物理的に考えるときには不可逆過程の 正しい取扱に基いた近代物性物理の体系によることが望 まれる。

外力としてズレの速度勾配が加えられたときに，溶媒 のみではいわゆるニュートン粘性を示すが，少量の高分 子を溶かすこと火よって非ニュートン性が現われ，通常 の角速度で岡性率を持つようになる。このような事実は かなり早くから濃厚溶液について確認されてきたが, 希 薄溶液については 1952 年 Mason らがねじれ水晶振子 を考案してポリイソブチレンなどの線状コイル分子の 1\%以下の溶液で㴊性率を測定するのに成功した1。

これらの研究とほぼ同じころに溶液の粘弾性を理諭的 火理解しようとする試みがなされた。Kirkwood は，鎖 状分子の 分子構造と内部自由度を正確に取入れて一般

* Hidejiro TANAKA北海道大学理学部高分子学数室

** Akio SAKANISHI 北海道大学理学部物理学科

Viscoelastic Properties of Dilute Polymer Solutions ( I )
的なセグメント分布関数の拡散方程式を導いだ2。線状 コイル分子については実験亡比較できる結果が得られ なかったが，内部自由度の涷結した棒状分子の場合は Kirkwood-Auer によって動的粘度と剛性率の分散が具 体的に求められだ)。さらに Cerf は剛体回転ダ円体に ついて同様なことを調べた4)。これらの研究に続いて， Rouse と Bueche は抵抗を代表する小球と内部自由度 を表現するフックバネの連鎖で線状コイル分子を置換え て，素抜けの場合の希薄溶液の粘弾性を求めた ${ }^{57,6) 。 ま ~}$ た Zimm は流体力学的相互作用を考慮して，非素抜け の場合の理論的結果を得た ${ }^{7), 8)}$ c

線状コイル分子について初めて分子論との 対応に成 功した希薄溶液の実験は第 1 図に示した Rouse-Sittel (1953) のポリスチレンートルエンの寒験である ${ }^{9}{ }_{c}$ 十分 希薄であったことと良溶媒であったため Rouse の素抜 け理論と良く一致した。その後 DeWitt らによってポ リイソブチレンーデカリンの $8 \%$ 程度の溶液では第 2 図 のように実験と Rouse 理論とはかなり違らことがわか った ${ }^{10)}$ 。さらに 1960 年代になって Birnboim-Ferryに よってポリ塩化ビニルージオクチルフェノールの $2 \%$ 溶 液の場合, 流体力学的相互作用孛入れた Zimm 理論と 似た剛性率の分散を示すことが知られた（第3図) ${ }^{11}$ 。

棒状分子について Kirkwood-Auer または Cerf の理 諭と一致する実験は容易には得られなかった

最近, 希薄溶液の分子諭的理解に 新しい試みがなさ れ，実験乱よび理論の多くの興味ある結果が得られてい る。その中で重要な問題のいくつかを取り上げて解説す る。 


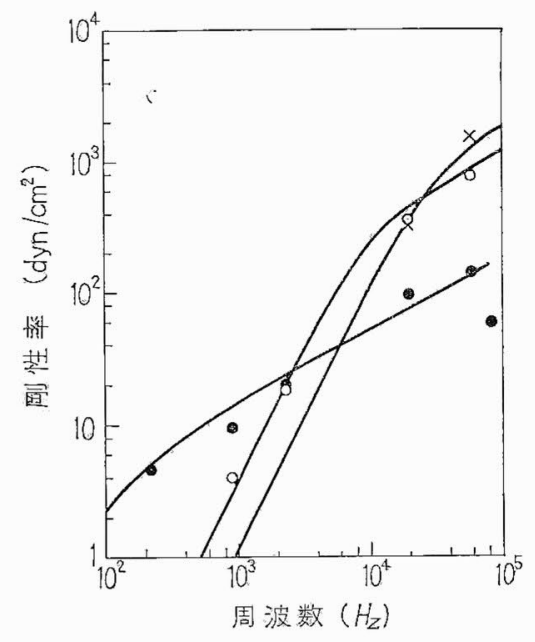

\begin{tabular}{|c|c|c|}
\hline & 分子䢜 & 磩度 $(\mathrm{g} / 100 \mathrm{cc}$ ) \\
\hline$\cdot x$ & 253000 & 1.48 \\
\hline 0 & 250000 & 0.89 \\
\hline (2) & 6200000 & 0.144 \\
\hline
\end{tabular}

第 1 図 Rouse-Sittel の剛性率の実験值と Rouse 理譣 ${ }^{9}$

\section{2. 粘弾性定数の現象論}

今, 時間 $t$ K゙ついて正弦的に变化するズレ $\gamma=\gamma_{0} e^{i \omega t}$ の变形を考光る。通常低分子夜体で性応力 $\sigma$ と変位速度 (速度勾配) $\dot{\gamma} の$ 間にニュートンの粘性の法則がなりた つ。

$$
\sigma=\eta \dot{\gamma}
$$

ここでクは粘度で角周波数 はそれに区して分散を示し，複素粘度 グとなる。

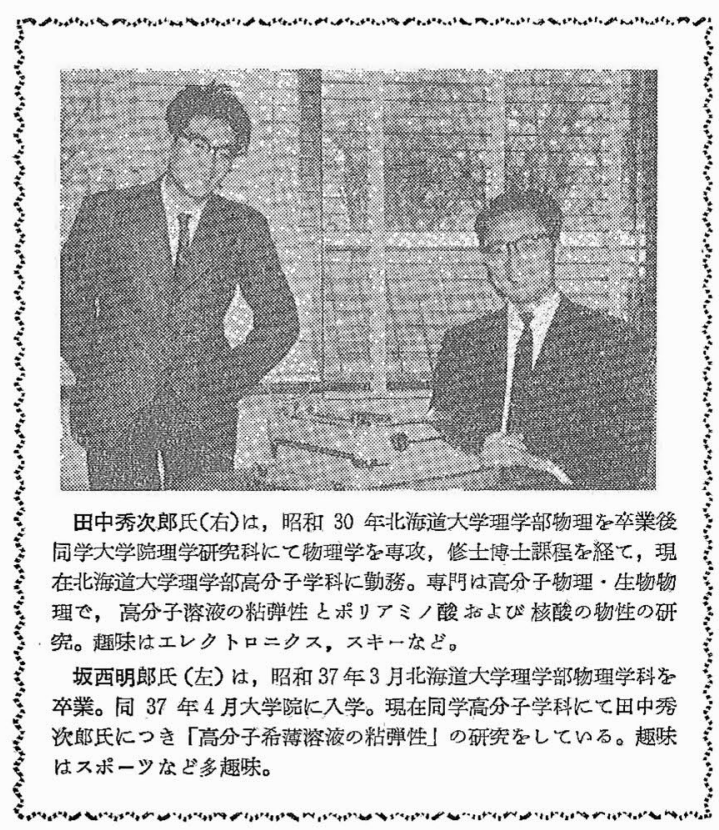

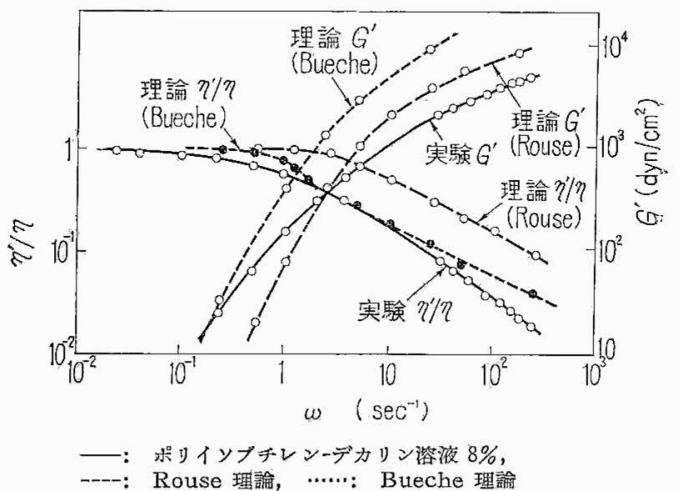

第 2 図準濃厚溶液の動的粘度と剛性率の 実験 と理論 ${ }^{10>}$

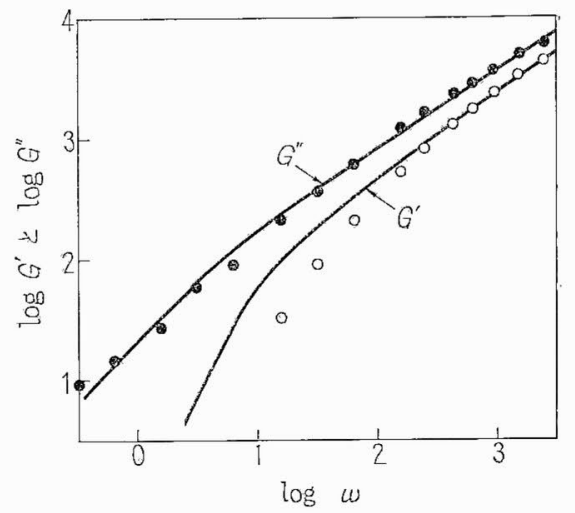

壏化ビニルージォクチルフェノール溶液 $2 \%$ の用性率の 実数部分 $(\mathrm{O})$ と虚数部分 $(0),-Z \mathrm{imm}$ 理論

第 3 図 Birnboim-Ferry の実驗 と Zimm 理諭 ${ }^{11)}$

$$
\eta^{*}=\eta^{\prime}-i \eta^{\prime \prime}=\eta_{\infty}+\sum_{p} \frac{\eta_{p}}{1+i \omega \tau_{p}}
$$

ここで $\eta_{\infty}$ は $\omega \rightarrow \infty$ の粘度または溶媒粘度 $\left(\eta_{s}\right)$, $\eta_{p}$ は $p$ 番目の緩和機構の定数, $\tau_{p}$ は緩和時間である。 一方フックの法則から定義される複素䣓性率 $G^{*}$ は

$$
G^{*}=i \omega \eta *
$$

によって関係づけられる。そこで（2）式より

$$
G^{*}=G^{\prime}+i G^{\prime \prime}=i \omega \eta_{\infty}+\sum_{p} \frac{G_{p} i \omega \tau_{p}}{1+i \omega \tau_{p}}
$$

ここで緩和強度 $G_{p}$ は

$$
G_{p}=\eta_{p} / \tau_{p}
$$

また, 複素コンプライアンス $J^{*}$ は次式で定義される。

$$
J^{*}=1 / G^{*}
$$

さらに $\omega \rightarrow 0$ の定常流粘度 $\eta$ と定常状態コンプライ アンス $J_{0}$ は去れぞれ

$$
\begin{gathered}
\eta=\eta_{s}+\sum_{p} \eta_{p}=\eta_{s}+\sum_{p} G_{p} \tau_{p} \\
J_{e}=\lim _{\omega \rightarrow 0} J^{\prime}=\lim _{\omega \rightarrow 0} \frac{G^{\prime}}{\omega^{2} \eta^{2}}=\sum_{p} \frac{G_{p} \tau_{p}^{2}}{\left(\eta_{s}+\sum_{p} G_{p} \tau_{p}\right)^{2}}
\end{gathered}
$$



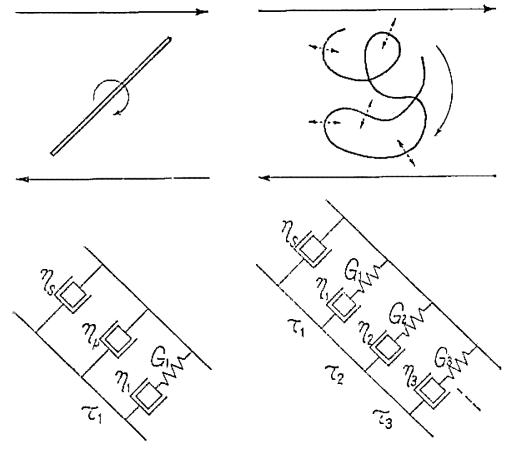

第 4 図 棒状分子と線状コイル分子の運動 と緩和の模形 ${ }^{13)}$

で与えられる。1 cc あたりの貯蔵エネルギーは $J_{e} \sigma^{2} / 2$, $1 \mathrm{cc}$ あたり $1 \mathrm{sec}$ あたりの散逸エネルギーは $\eta \dot{\gamma}^{2}$ と なる。

\section{3. 粘弾性の分子論}

高分子の最も特徵的なコンホメーションとして棒状分 子と線状コイル分子があげられる。第 4 図にそれらの . 運動様式と対応する (2)，(4) 式の定数を図式的に示す （ただしコイル分子の場合 $\eta_{\infty}=\eta_{8}$ ，棒状分子の場合 $\eta_{\infty}$ $\left.=\eta_{s}+\eta_{p}\right)^{132}$ 。以下この二つの分子形態を中心K粘弾性 の分子論を述べる。

\section{3-1. ルーズ模型による線状コイル分子の理論}

Rouse はエントロピー弾性のバネと摩擦係数を表すビ 一ズからなるセグメントの逨なりとしてコイル分子を代 表させたルーズ模型（第 5 図）によっで），離れたセグ メント間の相互作用がない素抜け（free-draining）の場 合の粘弾性を計算した ${ }^{5)}$ 。Zimm はルーズ模型にセグメ ント間の流体力学的相互作用を考慮して, 非素抜け (non-draining) の場合を計算した ${ }^{7)}$ c 結果は（2）式と (4) 式の定数については $G_{p}=n k T=c R T / M$ および $\eta_{\infty}$ $=\eta_{s}$ となり次式にまとめられる ${ }^{15)}$ 。

$$
\begin{gathered}
G^{*}=i \omega \eta_{s}+(c R T / M) \sum_{p} \frac{i \omega \tau_{p}}{1+i \omega \tau_{p}} \\
\eta^{*}=\eta_{s}+(c R T / M) \sum_{p} \frac{\tau_{p}}{1+i \omega \tau_{p}} \\
\tau_{p}=K_{p}\left(\eta-\eta_{s}\right) M / c R T
\end{gathered}
$$

ここで $n$ は $1 \mathrm{cc}$ 中の高分子数, $k$ はボルッマン定数,

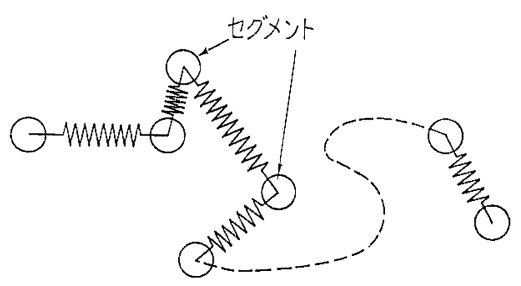

第 5 図ルーズ慔形 ${ }^{4)}$
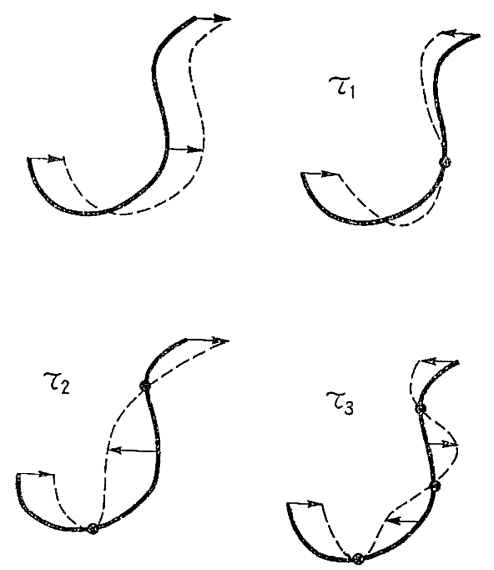

第 6 図 基準振動の最初の 4 個のモード14)

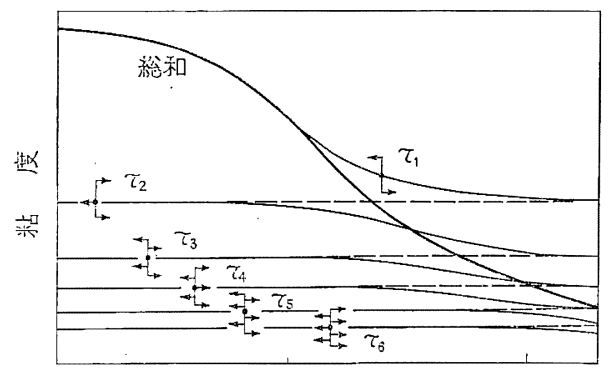

周波数の対数

第 7 図 各基準振動の緩和の動的粘度 ヘの等与 ${ }^{14}$

$T$ 絶体温度, $R$ 気体定数, $M$ 高分子の分子量, $c$ 濃度 $(\mathrm{g} / \mathrm{cc})$ で，緩和時間因子 $K_{p}$ が理諭によって異なる ${ }^{16)}$ 。 Rouse 理諭では $K_{p}=6 / \pi^{2} p^{2}$, Zimm 理諭では $K_{p}=1 /$ $0.586 \lambda_{p}{ }^{\prime}\left(\lambda_{p}{ }^{\prime}\right.$ は Zimm の固有值で $\lambda_{1}{ }^{\prime}=4.04, \lambda_{2}{ }^{\prime}=$ $\left.12.79 \ldots{ }^{8)}\right)$ 。

これらの理論は 1 次元の格子振動と対応がつき, 第 6 困に最初の 4 個の基準振動が図示されている ${ }^{14)}$ 。粘弾性 に寄与するのは並進運動を除いた 1 次のモードからで, これが最大緩和時間 $\tau_{1}$ にあたる。以下セグメントの数 $N$ 個のモードが緩和時間と対応し, それらが 動的粘度 $\eta^{\prime}$ に寄与寸る様子を Zimm 理論の場合について第 7 図 に示す十14

第 8 図に緩和スペクトルを $n k T$ で規格化して 緩和時 間因子に対して示す。実線は Rouse の素抜け理論, 破 線は Zimm の非素抜け理論を現わす。線スペクトルの $p=1 \sim 7$ までの $K_{p}$ の変化は素抜けの場合の方が大き い。連続スペクトルの勾配は Rouse の場合 $-1 / 2$, Zimm 理論で $-0.63\left(\approx-2 / 3, p \gg 1\right.$ の高周波の場合 $\left.{ }^{15)}\right)$

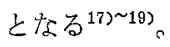

Tschoegl は Zimm 理論を拡張して部分的素抜けの場 合 ${ }^{20)}$ および排除体積効果を Ptitsyn-Eitzner の扱いで考 慮し ${ }^{21)}$, 両端間距離について 


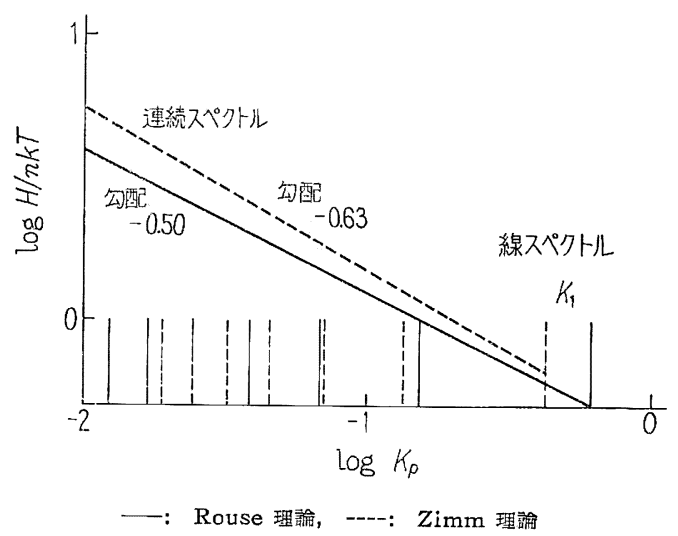

第 8 図緩和時間因子と緩和スペクトル

$$
<r^{2}>=b^{2} N^{1+\varepsilon}
$$

の Peterlin の広がりのパラメーター $\varepsilon^{22)}$ と非素抜けの パラメーター $h$ に対してより一般的な場合の粘弾性を数 值計算した ${ }^{23)}$ 。ここで $\left\langle r^{2}\right\rangle$ と $b^{2}$ はそれぞれ高分子 とセグメントの両端間距離の自乗平均である。結果はや はり (9)〜 (11) 式で書けるが, $K_{p}$ の值が $\varepsilon=0, h=\infty$ のZimm 理論のそれから $h=0$ の Rouse 理論 ( $\varepsilon$ によ らない）の值まで变化する。その様子を定常流固有粘度 について,

$$
[\eta]=\Phi 6^{3 / 2} \frac{<s^{2}>}{M}
$$

の Flory 定数 $\Phi^{2425)}$ を素抜け度 $h^{-1}$ と に対して $\Phi_{0}=2.84 \times 10^{23}$ で規格化して第 9 図に示す ${ }^{26) 27) 。 ~}$

最近 Fixman は流体力学的相互作用の Oseen テンソ ル28)の異方性をより正確に取入れて, 摂動の 0 次,一次, 二次まで計算しそれぞれ $\Phi_{0}=2.68,1.81,2.66 \times 10^{23}$ の 值を求めた。徒来のテンソルの Kirkwood-Riseman 近 似 ${ }^{29)}$ に比べて低次の $K_{p}$ を多少小さくする効果があ ๖ $^{30), 31)}$ 。

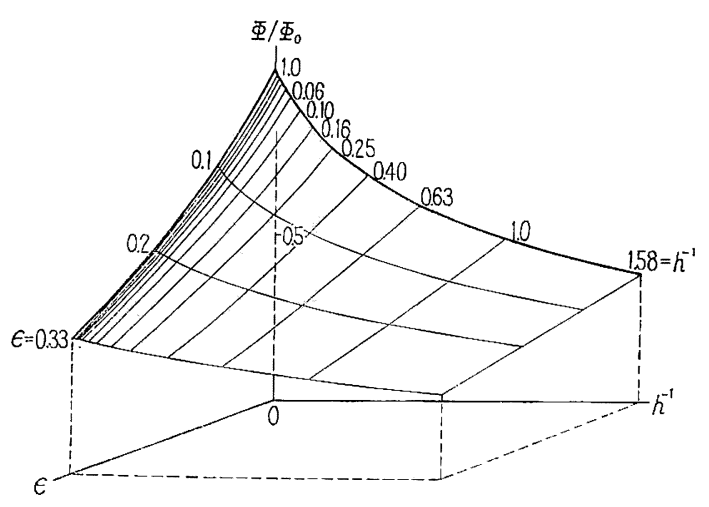

第 9 図 Flory 定数の広がりと素抜け度依存跣 (Tschoeg1 理論)

\section{3-2. 棒状分子の理論}

棒状分子の Kirkwood-Auer の粘弾性理論は $N+1$ 個 のビーズが長さbのリンクで刷く結合した模型により， 非素抜けの場合の結果を得だ)。また, 亜鈴模型 (dumbbell model) による理論の結果は古ょ5ど棒状分子の素 抜けの場合に対応する。いずれの場合も内部自由度の谏: 結に対応して単一緩和となるので (2) と (4) 式について は, $G_{p}=B c R T / M, \eta_{\infty}=\eta_{s}+A \tau c R T / M$ として緩和は一. 項のみとすると次式のように同じ形式で表わされる ${ }^{32)}$ c

$$
\begin{gathered}
G^{*}=i \omega \eta_{\mathrm{s}}+(c R T / M)\left[A i \omega \tau+\frac{B i \omega \tau}{1+i \omega \tau}\right] \\
\eta^{*}=\eta_{s}+(c R T / M)\left[A \tau+\frac{B \tau}{1+i \omega \tau}\right] \\
\tau=K\left(\eta-\eta_{s}\right) M / c R T
\end{gathered}
$$

ここで $A, B$ は分散定数， $K$ は緩和時間因子であって， Kirkwood-Auer 理諭では, $A=1 / 5, B=3 / 5, K=5 / 4$, 亜鈴模型の理論では $A=2 / 5, B=3 / 5, K=1$ である ${ }^{16)}$ 。

さらに 剛体回転ダ円体についての粘弾性理論もあ る4),33)。その場合 $A, B, K$ が軸比の関数になって, (14)〜(16) 式と同じ形に書ける ${ }^{34)}$ 。

\section{3-3. その他}

以上主に有限な $\omega$ の動的な場合を述べたが， $\omega=0$ の 定常流固有粘度の理論との関係は，第 1 表に示すが，線. 状コイル分子の溶液論に打ける素抜け効果の問題 ${ }^{27) ~ 29), ~}$ (横軸) ${ }^{35}$ ～41) と, 排除体積効果および他のコンホメー ション，たと壳ば球状 ${ }^{42,43)}$ 環状 ${ }^{44), 45)}$ 枝分かれ分子46),47》 (縦軸) などとの相関に执いて興味のある問題が多い。 その他棒状とコイル 分子の 中間の堅い線状分子 (stiff chain）の理論48) 53)，また高周波数に扣ける一定粘度 $\eta_{\infty}$ の存在 ${ }^{54)}$, セグメントの数 $N$ の有限性 ${ }^{55)}$, 分子量分

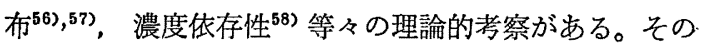
多くは理論的にも，特に実験的には，未解決な問題を含 んでいる。

\section{4. 実験と分子論との対応}

希薄溶液の分子論では通常分子 1 個の性質を求める。 したがって粘弾性の実験においても分子論との対応を考

\section{第 1 表 動的括よび定常流固有粘度の理論}

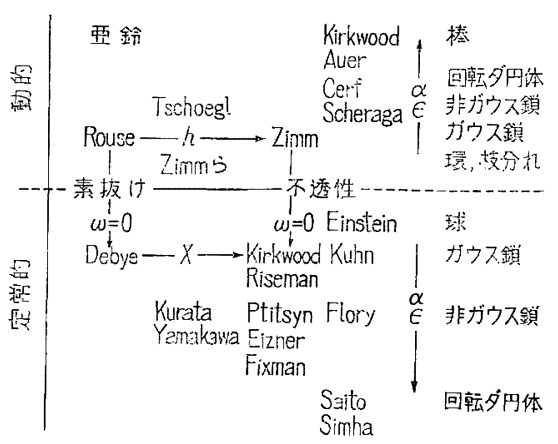


えるためには無限希薄に相当する量を取扱わねばならな い。

\section{4-1. 動的粘弾性}

そこで複素固有剛性率 (Complex Intrinsic Rigidity)

$$
\left[G^{*}\right]=\left[G^{\prime}\right]+i\left[G^{\prime \prime}\right]=\lim _{c \rightarrow 0}\left(G^{*}-i \omega \eta_{s}\right) / c
$$

と複素固有粘度 (Complex Intrinsic Viscosity)

$$
\left[\eta^{*}\right]=\left[\eta^{\prime}\right]-i\left[\eta^{\prime \prime}\right]=\lim _{c \rightarrow 0} \frac{\eta^{*}-\eta_{s}}{\eta_{s} c}
$$

とを導入する。 $\left[G^{*}\right]$ と $\left[\eta^{*}\right]$ は (3) 式から

$$
\left[G^{*}\right]=i \omega \eta_{s}[\eta *]
$$

で結ばれる ${ }^{16)}{ }^{\circ}$

一方緩和時間も濃度とともに変化する。そこで [G*], [ $\eta *]$ に対応する緩和時間として極限緩和時間 (Limiting Relaxation Time)

$$
\left(\tau_{p}\right)_{0}=\lim \tau_{p}(c)
$$

を考劣なければならない16) $\left(\tau_{p}(c)\right.$ は濃度 $c$ における緩 和時間)。これらを用いて 理諭の結果を次の無次元関数 (Dimensionless Functions) の形に整理することができ $\partial^{16)}$ 。

線状コイル分子に対しては $G^{*} を M / c R T$ で規格化 して（17）式を用いると（9）式から次式が得られる。

$$
\left.\begin{array}{c}
\frac{\left[G^{\prime}\right] M}{R T}=\sum_{p} \frac{\omega_{s}{ }^{2} K_{p}{ }^{2}}{\left(1+\omega_{s}{ }^{2} K_{p}{ }^{2}\right)} \\
\frac{\left[G^{\prime \prime}\right] M}{R T}=\sum_{p} \frac{\omega_{s} K_{p}}{\left(1+\omega_{s}{ }^{2} K_{p}{ }^{2}\right)}
\end{array}\right\}
$$

ここで $\omega_{s}$ は一般化角周波数 (Generalized Angular Frequency)

$$
\omega_{s}=\frac{\omega\left(\tau_{p}\right)_{0}}{K_{p}}=\frac{\omega \eta_{s}[\eta] M}{R T}
$$

で実験的にも一義的に決なる量である。ク*については 定常流固有粘度 [ク]で規格化して, (10) 式と (18) 式 から,

$$
\frac{\left[\eta^{\prime}\right]}{[\eta]}=\sum_{p} \frac{K_{p}}{1+\omega_{s}{ }^{2} K_{p}{ }^{2}}, \quad \frac{\left[\eta^{\prime \prime}\right]}{[\eta]}=\sum_{p} \frac{\omega_{s} K_{p}{ }^{2}}{1+\omega_{s}{ }^{2} K_{p}{ }^{2}}
$$

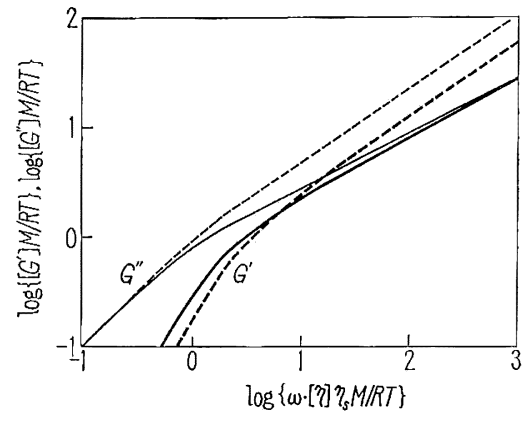

-: Rouse 理論, ----: Zimm 理論

第 10 図 線状コイル分子の複素固有 剛性率の理論曲線
のようになる。

棒状分子に対しても同様に次の形になる。((14), (15) 式より（22）式を用いて）

$$
\left.\begin{array}{l}
\frac{\left[G^{\prime}\right] M}{R T}=\frac{B \omega_{s}{ }^{2} K^{2}}{1+\omega_{s}{ }^{2} K^{2}} \\
\frac{\left[G^{\prime \prime}\right] M}{R T}=\frac{A \omega_{s} K+B \omega_{s} K}{1+\omega_{s}{ }^{2} K^{2}}
\end{array}\right\}
$$

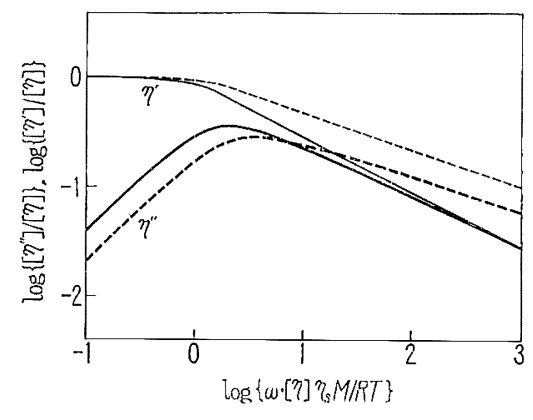

—: Rouse 理諭， ----:：Zimm 理論

第 11 図 線状コイル分子の複菜 固有粘度の理論曲線

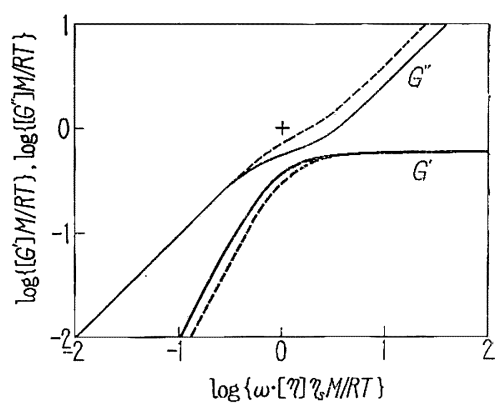

- $\mathrm{K}-\mathrm{A}$ 理猃, ----: 亚铪模形

第 12 図 棒状分子の複素固有剛性率 の理論曲線

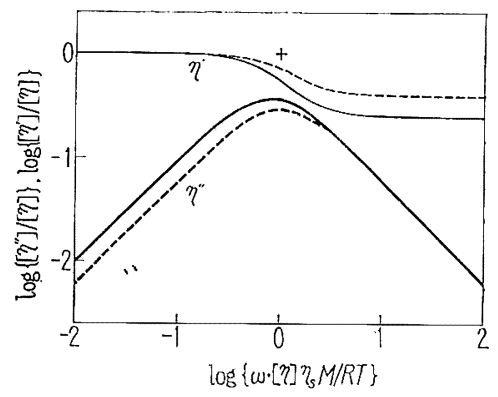

-： K-A 理論, ----: 垔铃模形

第 13 図 棒状分子の複素粘固有粘度 の理論曲線 
ここで無次元関数による Rouse と Zimm の理論曲 線を第 10 図と第 11 図に，Kirkwood-Auer と亜鈴模 型の理論曲線を第 12 図と第 13 図に示す。これらの無 次元関数表示によると理論と実駼の定量的な比較を一般 的に行なうことができる。その結果，高分子の分子内自 由度あるいはコンホメーションについての知見が得ら れる。ぬた，緩和時間因子の大きさ学決定でき，したが って緩和時間の合理的な見䅡りが可能となる。

\section{4-2. 定常流の粘弾性}

定常流では，粘性と弾性に刘応した固有量として

$$
\begin{aligned}
& {[\eta]=\lim _{c \rightarrow 0} \frac{\eta-\eta_{s}}{\eta_{s} c}} \\
& {\left[J_{e}\right]=\lim _{c \rightarrow 0} \frac{J_{e}}{c}}
\end{aligned}
$$

を考える。定常状態固有コンプライアンス $\left[J_{e}\right]$ は定常

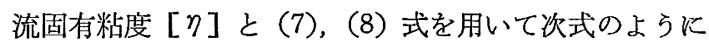
関係づけられる。線状コイル分子に対しては (9)〜 (11) 式より

$$
\left[J_{e}\right]=\sum_{p} \frac{K_{p}^{2}[\eta]^{2} M}{R T}
$$

棒状分子に対しては (14) (16) 式より

$$
\left[J_{e}\right]=\frac{B K^{2}[\eta]^{2} M}{R T}
$$

ここで $\sum_{p} K_{p}^{2}$ は Rouse 理論で 0.4, Zimm 理論で $0.206, B K^{2}$ は Kirlwwood-Auer 理論で 15/16, 亜鈴模 型の理論で $3 / 5$ である。また部分素拔けの非ガウス鎖の 場合も計算されている ${ }^{59)}$ 。

一方分子量依存性について，Mark-Houwink · 桜田 の式

$$
[\eta]=K_{\eta} M^{\alpha}
$$

で表わすと，(28）式または（29）式より定常コンプライ アンスについても

$$
\left[J_{e}\right]=K_{J} M^{2 \alpha+1}
$$

と書ける。 $\alpha$ は線状コイル分子の素抜けの場合 1 , 非素 抜けで 0.5, 棒状分子の素抜けの場合 2 , 非素抜けで 2 $-1 / \ln N, K_{\eta}, K_{J}$ は定数である。

\section{文献}

1) W. O. Baker, W. P. Mason, J. H. Heiss: J. Polymer Sci., 8, 129 (1952)

2) J. G. Kirkwood: Rec. Trav. Chim., 68, 649 (1949); J. Polymer Sci., 12, 1 (1954)

3) J. G. Kirkwood, P. L. Auer: J. Chem. Phys., 19, 281 (1951)

4) R. Cerf: Compt. Rend., 234, 1549 (1952); J. Phys. Rad., 13, 458 (1952); Fortshr. Hochpolym. Forsch., 1, 382 (1959)

5) P. E. Rouse, Jr.: J. Chem. Phys., 21, 1272(1953)
6) F. Bueche: J. Chem. Phys., 22, 603 (1954)

7) B. H. Zimm: J. Chem. Phys., 24, 269 (1956)

8) B. H. Zimm, G. M. Roe: J. Chem. Phys.. 24, 279 (1956)

9) P. E. Rouse, Jr., K. Sittel: J. Appl. Phys., 24, 690 (1953)

10) T. W. DeWitt, H. Markovitz, F. J. Padden, Jr., L. J. Zapas: J. Colloid Sci., 10, 174 (1955)

11) M. H. Birnboim, J. D Ferry: J. Appl. Phys., 32, 2305 (1961)

12) J. D. Ferry, F. E. Helders: Biochim. Biophys. Acta, 23, 569 (1957)

13) J. D. Ferry: Rev. Mod. Phys., 31, 130 (1959)

14) B. H. Zimm: Rheology III, 1 (1960), ed. F.R. Eirich, Academic Press Inc. N. Y.

15) J. D. Ferry: Viscoelastic Properties of Polymeres, John Wiley \& Sons, Inc., (1961), N. Y.

16) H. Tanaka, A. Sakanishi, M. Kaneko, J. Furuichi: J. Polymer Sci., C15, 317 (1966); 材料, 15, 302 (1966)

17) O. Nakada: J. Phys. Soc. Japan, 10, 804 (1955)

18) N. Saito, K. Okano, S. Iwayanagi, T. Hideshima: Solid State Phys., 14, 343 (1963); ed. F. Seitz, D. Turnbu11, Academic Press Inc. N. Y.

19）山本三三三: レオロジー。槙書店 (1964)

20) N. W. Tschoeg1: J. Chem. Phys., 39, 149(1963)

21) O. B. Ptitsyn, Yu. E. Eizner: Zh. Fiz. Khim., 32, 2464 (1958); Zh. Tekhn. Fiz., 29, 1117 (1959)

22) A. Peterlin: J. Chem. Phys., 23, 2464 (1955); Ann. N. Y. Acad. Sci., 89, 578 (1961)

23) N. W. Tschoegl: J. Chem. Phys., 40, 473(1964)

24) P. J. Flory, T. G. Fox: J. Am. Chem. Soc., 73, 1904 (1951)

25) P. J. Flory: Principles of Polymer Chemistry, Ithaca, N. Y., Cornell University Press (1953)

26) J. E. Hearst: J. Chem. Phys., 37, 2547 (1962)

27) R. Ullman: J. Chem. Phys., 40, 2193 (1964)

28) J. M. Burgers: Second Report on Viscosity and Plasticity Chap. 3, Amsterdam (1938)

29) J. G. Kirkwood, J. Riseman: J. Chem. Phys., 16, 565 (1948)

30) M. Fixman: J. Chem. Phys., 42, 3831 (1965)

31) C. W. Pyun, M. Fixman: J. Chem. Phys., 42, 3838 (1965); 44, 2107 (1966)

32）斎藤信彦：高分子物理学，改訂版，第 7 章, 裳華房 (1967)

33) N. Saito: J. Phys. Soc. Japan, 6, 297, 302(1951)

34) H. A. Scheraga: J. Chem. Phys., 23, 1526 (1955) 
35) W. Kuhn, H. Kuhn: Helv. Chim. Acta, 26, 1394 (1943)

36) P. Debye: J. Chem. Phys., 14, 636 (1946)

37) P. Debye, A. M. Bueche: J. Chem. Phys., 16, 573 (1948)

38) M. Kurata, H. Yamakawa: J. Chem. Phys., 29, 311 (1958)

39）河合 徹：高分子の物性, 71, 化学同人 (1962)

40) M. Kurata, H. Stockmayer: Fortschr. Hochpolymer-Forsch., 3, 196 (1963)

41) K. Kamide, W. R. Moore: Makromol. Chem., 80, 225 (1964); J. Polymer Sci., B2, 1029 (1964)

42) A. Einstein: Ann. d. Phys.(4), 19, 289 (1906); 34, 591 (1911)

43) R. Cerf: J. Chem. Phys., 20, 395 (1952)

44) V. Bloomfield, B. H. Zimm: J. Chem. Phys., 44, 315 (1966)

45) M. Fukatsu, M. Kurata: J. Chem. Phys., 44, 4539 (1966)

46) J. S. Ham: J. Chem. Phys., 26, 625 (1957)

47) B. H. Zimm, R. W. Kilb: J. Polymer Sci., 37,
19 (1959)

48) T. Onishi, M. Yamamoto: J. Phys. Soc. Japan, 13, 1439 (1958)

49) J. E. Hearst: J. Chem. Phys. 40, 1506 (1964)

50) R. A. Harris, J. E. Hearst: J. Chem. Phys., 44, 2595 (1966)

51) J. E. Hearst, R. A. Harris: J. Chem. Phys., 45, 3106 (1966)

52) N. Saito, K. Talkahashi, Y. Yunoki: J. Phys. Soc. Japan, 22, 219 (1967)

53）斎藤信彦：日本物理学会第 22 回年会予稿集(1967)

54) A. Peterlin: J. Polymer Sci., A2, 179 (1967)

55) J. D. Ferry: J. Polymer Sci., C15, 307 (1966)

56) W. L. Peticolas: J. Chem. Phys., 35, 2128 (1961); Rubber Chem. Technol., 36, 1422 (1963)

57) S. E. Lovell, J. D. Ferry: J. Phys. Chem., 65, 2274 (1961)

58) M. Yamamoto, H. Tanaka: J. Macromol. Sci. (Phys.), B1 (2) 199 (1967); 材料, 15, 307(1966)

59) N. W. Tschoeg1: J. Chem. Phys., 44, 2331 (1966); J.Chem. Phys., 44, 4615 (1966)

\section{研究論文集「高分子化学」内容紹介}

\section{高分子の物理, 化学拉よび一般基礎工学の研究論文 第 24 巻・第 272 号・ 1967}

\section{[物 理]}

[106] 大型カラムの製作とそのカラムによるポリェチレンの分別

·林 誠一・浜田交将・西城 彰·中島章夫

[107] 大型カラムによるポリプロピレンの分別

西城 彰・林 誠一・浜田交将・中島章夫

[108］結晶性高分子のカラム分別における担体への沈着温度について

\section{[化 学 $]$}

[109] 無水マレイン酸のコポリマー

第 8 報 アリルグリシジルェーテルと無水マレイン酸のラジカル共重合・・野間夹之・丹羽政三

[110] イタコン酸誘導体の重合と重合体の研㠰

第10報 高温に拈けるイタコン酸無水物の熱重合とシトラコン酸無水物への転位

[111]放射線によるポリエチレン単結晶累積膜へのスチレングラフト共重合

永井 進·吉永安司 吉四経之助

[112] 炭酸ジビニルの共重合

高松俊昭·古永捷慶・深田栄一

[速 報]

[113] 定常流下の動的粘性

·菊川 清·野桜俊一・村橋俊介

高分子学会論文集 “高分子化学” 総目次（第 24 巻・第 261～272 号 - 1967）

著者名索引（研究論文集 “高分子化学”第 24 巻・第 261～272 号・ 1967) 